\title{
UNITED NATIONS RULE OF LAW, "COMMON LANGUAGE OF JUSTICE" AND THE POST-2015 EDUCATIONAL AGENDA: SOME ACADEMIC AND POLICY ASPECTS
}

For Maja - my granddaughter

\begin{abstract}
This interdisciplinary article first discusses some theoretical precepts of language and logic, then contextualizes them for the application of the United Nations (UN) Rule of Law. Next it argues that, while the international English language used in the Organization reflects specific national legal reasonings, the UN, by its nature, should harmonize Western and Eastern ways of thinking as they both contribute to the UN multivalent logic pursued for progressive ends. In conclusion, the article emphasizes that, notwithstanding the rather limited UN capacity for directly responding to educational justice needs across the world, UN rule-of-law evidence-driven recommendations and policies should have a more effective impact on justice education at all levels in the post-2015 UN Rule of Law agenda than they currently do.
\end{abstract}

Keywords

culture - education - justice - language - logic rule of law - United Nations

\footnotetext{
* Former Adjunct, Law Faculty, Nicolaus Copernicus University (Toruń); dr. hab. (Law/Criminology); Privatdozent, Vienna University; former UN Senior Crime Prevention and Criminal Justice Expert and UN staff (ret.); co-editor of 2 and author of 3 criminological books and about 60 other publications, mostly on UN rule-of-law education and training; email: s@redo.net.
} 
CAESAR [recovering his self-possession]:

Pardon him, Theodotus: He is a barbarian, and thinks that the customs of his tribe and island are the laws of nature.

George Bernard Shaw, 1899, Caesar and Cleopatra, Act 2

[T]here are a great many degrees of closeness or remoteness in human society. To proceed beyond the universal bond of our common humanity, there is the closer one of belonging to the same people, tribe, and tongue, by which men are very closely bound together; it is a still closer relation to be citizens of the same city-state.

Cicero, 44 B.C, De Officiis ${ }^{1}$

\section{INTRODUCTION}

This article was prompted by two experiences: the author's 30-year UN service (with three years spent in Central Asia), and the reaction of international students to his university course on The United Nations and Crime Prevention. Both international experiences have reinforced the idea that conveying a UN rule-of-law message across interculturally diverse audiences requires special approaches to reach each individual. In order to understand their thinking and communicate effectively with them, with a view to motivating and encouraging them to develop their reformist opinions, the author has attempted to conceptualize some elements of this process, which are presented below.

Delivering practical education in $\mathrm{UN}$ rule-of-law issues requires various tools. While in each country those issues and the meaning of the rule of law are different, comparative studies and common approaches are needed to address those issues effectively for the rule of law worldwide.

To date, in comparative law literature, the analysis of the rule of law has mostly been dealt with in academic terms by, for example, comparing the English-language ${ }^{2}$ term with the French or Chinese equivalent.

1 Cicero, De Officiis, With an English Translation by Walter Miller, London, William Heinemann Ltd, New York: G. R Putnam's Sons 1913, p. 57.

2 The term "language" will be used in this article together with other adjectives such as colloquial, like "native", theoretical, like "normative" or "natural", metaphorical like 
Academic lawyers analyze whether or not these terms are synonymous and then note the different functional uses of apparently similar, if not identical, normative terms ${ }^{3}$.

However, the functional meaning of the rule of law varies from country to country. Given that academics have established this to be the case between two countries, what are the implications of such differences in understanding among the 28 countries of the European Union (EU) or the 193 Member States of the UN? Or the normative impact and functions of the rule of law among what the UN describes as "peoples", that is, single nations, tribes or clans, given that in developing countries, traditional methods of resolving disputes can be the primary means of access to justice? Finally, what about the UN rule-of-law impact on single people?

To enhance practical rule-of-law education at all levels, this article seeks to provide some answers to these questions in the framework of United Nations Studies4. By virtue of its Charter, the core focus of the UN is on peace: saving succeeding generations from the scourge of war. From this core branched out a variety of related Studies, including UN Rule of Law Studies.

This article touches on the classical comparative understanding of the definition of the rule of law and related terms in the context of tertiary (graduate) legal education. It provides examples of the idiosyncrasies and incongruences of legal translation, then proceeds to the relatively uncharted waters of the UN understanding of the rule of law, in particular to a reexamination of one classical canon of Western law: its formal $\operatorname{logic}^{5}$. The article then considers the implications

\footnotetext{
"common", the "UN language" or "language of mediation". No inferences should be made for taking one type of language for another.

3 J. Wróblewski, Comparative law and legal language. Some methodological problems, Comparative Law Review 1988, vol. 1, p. 18; M. Stephenson, A Trojan horse in China?, [in:] T. Carothers (ed.), Promoting the Rule of Law Abroad. In Search of Knowledge, Washington, D.C.: Carnegie Endowment for International Peace 2006, pp. 191-216.

4 J. Harfensteller, The United Nations and Peace. The Evolution of an Organizational Concept, Frankfurt am Main-Berlin-Bern-Bruxelles-New York-Oxford-Wien: Peter Lang 2011, p. 2.

5 The term "logic" will be used in this article with several adjectives (theoretical, like "formal', "normative", "bivalent", "multivalent"; anthropological like "tribal"; political science like "UN" and "hegemonial") which refer to individual or/and aggregate reasoning,
} 
for intercultural ${ }^{6}$ education on the UN conception of the rule of law $^{7}$ in the light of the lessons learned from donor technical assistance failures for national capacity-building in developing countries, which could be accounted for by a latent ethnocentric assumption that all actors participating in an intercultural rule-of-law education think in the same way.

There was no doubt about the approach to take when in the beginning of the 1950s the United States (US) started its "Law and Development Movement" to help to reform in developing countries tertiary legal education, with the aim of developing greater freedom, equality and democratic participation in public life ${ }^{8}$. With no needs assessment tools to enable it to find out first what had been the root causes of the existing failings of the tertiary legal education system and the idealism to turn lawyers into legal activists vested with the promotion of the rule of law according to the US standards, by the mid-1970s the Movement had come to a standstill. Then it was realized that making legal institutions in developing countries more like the US would not be possible. They were found alien to local contexts and the values inculcated in them by family, tribe, religion, culture and other forces?.

From today's development assistance perspective, such forces must be regarded as fundamental for successful rule-of-law education at any level. It is from this perspective that this article re-examines the ethnocentric assumption persisting until today of one logic (individual and collective) for conveying internationally and interculturally rule-of-law

scientific or not. Save the "UN" and "multivalent" logic, no inferences should be made for taking one kind of logic for another.

6 With this word in the article are especially connected "Western" ("Occidental"), Eastern ("Oriental") ways of thinking, respectively formal and tribal logic and tribalism. These are not fully replicable by one another, but there is no way for a more systematic and rigorous delineation of them.

7 This is also done in her own terms by Harfensteller (idem, supra note 4), especially in ch. 1 in which she explains the role of language in international organizations.

8 M.J. Trebiblock and R.J. Daniels, Rule of Law Reform and Development, Charting the Fragile Path of Progress, Cheltenham-Camberley-Northampton: Edward Elgar 2008, p. 280.

9 M. Schönteich, The Rule of Law Movement. A Review of Its Origins, Evolution and Ambitions. In L. Mooney, Promoting the Rule of Law. A Practitioner's Guide to Key Issues and Developments with Foreword by Justice R.J. Goldstone, Chicago: ABA Section of International Law 2013, pp. 27-46. 
precepts, and looks into the ways through which education challenges may be overcome for the UN in this regard.

In arriving at the conclusions, the article projects from the academic world into the UN world concepts, terms or issues that may be relevant to its better understanding. "Logic", "language universals"10 or "universalism $v$. relativism" 11 known as such in academia, have their own import and meaning in the UN. But extrapolating them directly into the UN world is only partly possible. Possible is also their metaphorical interpretation. Consequently, save a couple of points on logic, and UN universalism interpreted in its original sense, the balance of this article keeps to the metaphorical interpretation ${ }^{12}$.

First, however, this article starts with explaining what exactly is meant in the UN by the "rule of law", "justice" and "a common language of justice". Then it examines language and logic as its two instruments for practical rule-of-law education. In addressing them, the article emphasizes the need to remember about another, this time correct, intercultural assumption. Namely that in people's thinking moral choices and outcomes are guided by kinship or tribal and, broader, contractual reasons. In conclusion, the article reemphasizes the importance

10 The discussion over them started with Al Farabi (c. 872 - c. 950) one of the most prominent Arabic successors to Aristotle's logic. With his fellow logicians Al Farabi argued that all humans have fixed categories of the mind which determine their perception of the world, regardless of the language they speak ( $\underline{\mathrm{S}}$. Abed, Aristotelian Logic and the Arabic Language, Albany: SUNY 1991, p. 168). In this spirit, Joseph Greenberg and Noam Chomsky (US linguists and logicians) argue that there are linguistic universals - a pattern that occurs systematically across natural languages, potentially true for all of them. For instance, all languages have nouns and verbs, or if a language is spoken, it has consonants and vowels. Available online: http://en.wikipedia.org/wiki/Linguistic_universal [last accessed: 10.12.2013].

11 In the linguistic field, relativism counters the concept of linguistic universals (footnote above). One of the most prominent expositions of that is "the Sapir-Whorf hypothesis" (P. Kay, W. Kempton, What is the Sapir-Whorf Hypothesis?, American Anthropologist 1984, vol. 86, issue 1, pp. 65-79). In other disciplines the controversy between one and the other approach is known as "universalism $v$. particularism" (international management theory), "universal v. specific" (philosophy, public international law), etc. Drawing on the views from those other disciplines, this article takes a universalistic justice perspective, in line with the global values of the United Nations Charter and the Organization's other rule-of-law instruments.

12 Which is academically sustainable ("Much of science is conducted through models, and models are nothing else than elaborated and determinate metaphors", R.H. Brown, A Poetic for Sociology, Cambridge: Cambridge University Press 1977, p. 113). 
of enhancing the UN Rule of Law, by stressing the importance of pursuing one sense of justice, as interpreted in the UN and by other like-minded actors.

In this manner the article addresses: "[s]uccesses and challenges in implementing comprehensive crime prevention and criminal justice policies and strategies to promote the rule of law at the national and international levels, and to support sustainable development" - the topic on the agenda of the Thirteenth UN Congress on Crime Prevention and Criminal Justice (Doha, Qatar, 2015), and seeks to contribute to the post-2015 UN rule-of-law agenda.

\section{WhAT IS THE "RULE OF LAW" IN THE UNITED NATIONS?}

There is no logic without language, but are there inter-language fixed logical categories valid for all nations? If so, are such categories applicable in the UN normative work?

It may come as another surprise that a positive reply to both questions could for a long time only be inferred ${ }^{13}$. Finally, in 2004 the Secretary-General clearly defined in a highly purposive and distinctive "moral language"14 (see the added emphases) for its Secretariat that: "[t]he 'rule of law' is a concept at the very heart of the Organization's mission. It refers to a principle of governance in which all persons,

13 From the the first mention of this term in 1948 by the Universal Declaration of Human Rights ("Whereas it is essential (...) that human rights should be protected by the rule of law"), and the 1999 working paper for the Tenth UN Congress on the Prevention of Crime and the Treatment of Offenders which first considered some constitutive elements of the rule of law, but took no action (UN doc. A/CONF. 187/3, Promoting the Rule of Law and Strengthening the Criminal Justice System, 14 December 1999, §§ 5-20).

14 R. Tuck, The Rights of War and Peace. Political Thought and International Order from Grotius to Kant, Oxford: Oxford University Press 2002, p. 149. A discussion whether or not minimum human sociability and cooperation is naturally/inherently moral or imposed by positive law started with Thomas Hobbes (1588-1679), Hugo Grotius (1583-1645) and Samuel Pufendorf (1632-1694), the founders of public international law (see further: P.C. Westerman, The Disintegration of Natural Law Theory. Aquinas to Finnis, Leiden-New York-Köln: Brill 1998, ch. 7). Since then natural scientists, social scientists and non-academics have debated over biological and social issues of sociability and cooperation. The language of the Universal Declaration of Human Rights referring to "barbarous acts which have outraged the conscience of mankind", and to the promotion of "social progress and better standards of life in larger freedom" blends morality as a natural human value with provisions on reformatory processes aimed at arrangements for better access to justice globally. 
institutions and entities, public and private, including the State itself, are accountable to laws that are publicly promulgated, equally enforced and independently adjudicated, and which are consistent with international human rights norms and standards. It requires, as well, measures to ensure adherence to the principles of supremacy of law, equality before the law, accountability to the law, fairness in the application of the law, separation of powers, participation in decision-making, legal certainty, avoidance of arbitrariness and procedural and legal transparency" 15 .

In 2012 the General Assembly in a likewise purposive and moral fashion considerably expanded the rule of law principles, drawing on the UN Charter and other "principles of justice and international law". As in the above-quoted definition, it made them different from "justice" ("respect for and promotion of the rule of law and justice") and declared these rule-of-law principles as universally applicable by Member States. The rule of law, the Declaration states, is fundamentally important for political dialogue and cooperation, and conducive to the improvement of international peace and security, human rights and development ${ }^{16}$.

\section{What IS "JUSTICE" IN THE UNITED Nations?}

The UN Charter mentions "justice" in various places and ways. But it neither defines what it means by justice nor differentiates between international justice, justice among nations, social justice, justice among people or climate justice. The Charter's commentaries either skip the explanation of what "justice" is or say only that the Preamble's wording suggests it to be distinct from "justice" arising from treaties and other

15 UN doc. S/2004/616, Rule of Law and Transitional Justice in Conflict and Post-Conflict Societies, Report of the Secretary-General to the Security Council, 3.08.2004, § 6 .

16 UN doc. A/RES/67/1, Declaration of the High-level Meeting of the General Assembly on the Rule of Law at the National and International Levels, 24.09.2012. 
sources of international law. "To that extent the Preamble refers to natural law"17.

Therefore, while in international law "justice" may have different meanings, especially as per its stipulations, in its doctrine it indeed has a natural law connotation. However, going into its specifics would be fraught with difficulty: for example, Aristotle regarded slavery as natural justice, and G.B. Shaw put a tribal notion of justice into the mouth of Caesar (see beginning of the present article). In various UN legal instruments, "justice" variously implies "fairness" or another value $^{18}$. A report of the Secretary-General to the Security Council states that "justice" is "an ideal of accountability and fairness in the protection and vindication of rights and the prevention and punishment of wrongs. Justice implies regard for the rights of the accused, for the interests of victims and for the well-being of society at large"19. Such widely differing notions of "justice" give an inkling of the challenge of determining exactly what is meant by this term in the UN20.

17 B. Simma, H. Mosler, A. Randelzhofer, Ch. Tomuschat, R. Wolfrum, A. Paulus, E. Chaitobu (eds), The Charter of the United Nations: A Commentary, New York: Oxford University Press 2002, vol. 1, p. 36.

18 For example, a UN publication argues that "economic justice" is replaceable by "equality" and "equity" (UN. Doc. ST/ESA/305, The International Forum for Social Development. Social Justice in an Open World. The Role of the United Nations, New York: United Nations 2006, pp. 15-16). In other internationally sourced interpretations, "equity" in education has two dimensions. The first of these is fairness. It implies "ensuring that personal and social circumstances, e.g. gender, socio-economic status or ethnic origin, should not be an obstacle to achieving educational potential". The second is inclusion. It implies "ensuring a basic minimum standard of education for all - for example that everyone should be able to read, write and do simple arithmetic". These two dimensions are closely interrelated: tackling school failure helps to overcome the effects of social deprivation that often causes school failure (S. Field, M. Kuczera, B. Pont, No More Failures. Ten Steps to Equity in Education, Paris: OECD 2007, p. 10). It seems that the above terms ("equality" /"equity") are really intellectual shortcuts ("poverty" is another one) suggesting that UN "justice", however nominally termed, is about addressing and redressing by democratic States and other actors humanitarian, rights- or/and evidence-based relational deprivations.

19 UN doc. S/2004/616, supra note 15, § 7.

20 It thus seems pointless to insist on one literal meaning of "justice" in United Nations law and practice, because functionally it is a developmental concept of an international public good, credited to natural law. For a review of this process in criminal justice terms, see further: S. Redo, M. Platzer, The United Nations' Role in Crime Control and Prevention, [in:] J. Albanese, R. Reichel (eds), Handbook of Transnational Crime and Justice, Los AngelesLondon-New Delhi-Singapore-Washington D.C.: Sage Publications 2013, pp. 293-294). 


\section{What IS "COMMON LANGUAGE OF JUSTICE"?}

In the report cited above, the Secretary-General envisions "justice" as an international developmental public good that should be attained through interagency operational work across the world, with a view to building "a common language of justice". Headed in $\S 5$ by this metaphorical term, the same report explains next that: "Concepts such as 'justice', 'the rule of law' and 'transitional justice' are essential to understanding the international community's efforts to enhance human rights, protect persons from fear and want, address property disputes, encourage economic development, promote accountable governance, and peacefully resolve conflict. They serve both to define our goals and to determine our methods. Yet, there is a multiplicity of definitions and understandings of such concepts, even among our closest partners in the field. At an operational level, there is, for some, a fair amount of overlap with other related concepts, such as security sector reform, judicial sector reform and governance reform. To work together effectively in this field, a common understanding of key concepts is essential"21.

In short, the report acknowledges that in the UN the level of intergovernmental and interagency field coordination on functional justice issues has been limited and a partner agreement would need to be established in order to increase it.

It is clear that the above concept of a "common language of justice" in its substance and scope is something different from academically understood legal meta-language ${ }^{22}$. Yet that does not render academic interpretation of that UN "language" superfluous. The following observations therefore address three capacity-building instruments: language, logic, and education, all of which are relevant to "a common language of justice" in the UN.

Likewise, from this international perspective, it may be pointless to look for one theoretical understanding of "justice" and its agreed reception in various legal cultures.

21 Ibidem, §5.

22 S. Šarčević, New Approach to Legal Translation, The Hague: Kluwer 1997, ch. 4. 


\section{LANGUAGE AS AN INSTRUMENT IN INTERCULTURAL (MIS)UNDERSTANDING OF WHAT JUSTICE IS}

In terms of the substance of "justice", for native English speakers and others who implement $\mathrm{UN}$ projects aimed at providing "access-to-justice", the term implies the literary Western concept that was largely codified in the UN global hard and soft law instruments. It is represented by the Hellenic and Roman mythoi blindfolded Themis/Justitia, with a sword and the Scales of Justice. Such a conception of justice may not be shared by Arabs, Chinese, Indians or billions of others, despite the existence now of a single UN definition of justice, and a single developmental sense of "fairness", as experimentally proven in game theory ${ }^{23}$.

If Westerners want to understand what "justice" may mean for, say, Chinese, they must return to its multi-entitical, contextual and cosmological meaning. It is consistent with the non-Aristotelian way of thinking about the "non-existent" (in terms of his formal logic only). A pair of ideograms shows what "'justice" looks like: 正义. Literally, the character 正 means situated in the middle, without left or right, thus meaning impartial, without prejudice. The character 义 means righteousness, justice. B oth emphasize the meaning of impartial, without prejudice ${ }^{24}$. This exemplifies only one of the many idiosyncrasies of all the languages that meet in the UN, a place of multivalent or ambiguous logic, legal pluralism, and multiculturalism ${ }^{25}$.

The following explanation should help to understand how the UN "language" differs from other "justice languages", how the UN counters the literal and substantive differences with other justice languages, and how it overcomes these differences in the name of the rule of law.

\footnotetext{
${ }^{23}$ H. Gintis, The Bounds of Reason. Game Theory and the Unification of Behavioral Sciences, Princeton: Princeton University Press 2009, ch. 3. For a discussion of the common features of fairness that may be normatively developed, see: S. Redo, The UN Criminal Justice System in the Suppression of Transnational Crime, [in:] N. Boister, R. Currie (eds), The Routledge Handbook of Transnational Criminal Law, Abingdon, Oxon: Routledge 2014, forthcoming.

24 The author thanks Prof. Yingjun Zhang, Law School, South-Central University for Nationalities (Wuhan, The Peoples' Republic of China) for her assistance.

25 See, e.g. H. Nakamura, The Ways of Thinking of Eastern Peoples, compiled by Japanese National Commission for UNESCO, Westport: Greenwood Press 1960.
} 
Before arriving at this third point, two earlier points should be addressed, starting with the literal translations of what "justice" was historically taken to be. Another example shows this.

In a Central Asian legal text from the $4^{\text {th }}$ century B.C. translated into Chinese, historians found language indicating dominance and subjugation. Instead of: "[t]he husband supports his wife" and "[t]he wife looks after her husband" in the original, the text was translated as "[t]he husband controls his wife", and "[t]he wife respects her husband" 26 . Both translations emphasize the norms and bonds of filial piety in the spirit of Confucian social harmony ${ }^{27}$.

With that early example of a legal text overlaid with a power relation to give a different cultural meaning ${ }^{28}$ may be juxtaposed an example of the Orchon script ${ }^{29}$ from East Asia dating from the $8^{\text {th }}$ century A.D. Written by conservative nomads, it shows their suspicion and mistrust of the "cunning" Chinese: "[ $t$ ]he words of Chinese have always been sweet, their textiles are soft. Through their sweet words and soft textiles, the Chinese, so one says, draw the distant peoples in. And then they plan, so one sees, to make matters worse for such peoples, as soon as they settle nearby them. With this they prevent veritable clever and upright people from making progress" 30 .

In contrast, the Nestorians ${ }^{31}$, who operated among the Turkic nomadic tribes of East Asia between the $4^{\text {th }}$ and $14^{\text {th }}$ centuries A.D., did win the trust of nomads. They did so because, unlike the other religious competitors, they: "apparently overcame the biggest challenge in dealing with local groups speaking in different languages, that is they found in their language words equivalently communicating difficult notions (...). Because of this, they became close (...) to the nomads, and their teachings had been

\footnotetext{
26 T.O. Hölmann, Die Seidenstrasse [The Silk Road], München: Verlag C. H. Beck 2007, p. 49.

27 "Ruler to Ruled, Father to Son, Husband to Wife, Elder Sibling to Younger Sibling, Friend to Friend". See further: R. Fan, Reconstructionist Confucianism. Rethinking Morality After the West, Dordrecht-Heidelberg-London-New York: Springer 2010.

28 M. Danyté, Translation and Other Transcultural Acts: Resistance to Language Imperialism in the Age of English, Otherness: Essays \& Studies, vol. 3, no. 1, p. 8, available online: http://www.otherness.dk/otherness-essays-studies-3.1/ [last accessed: 10.12.2013].

29 Oldest known example of Turkic writings from that region wherefrom nomadic tribes invaded China and then Europe and the Middle East.

30 Hölmann, supra note 26, p. 53.

31 A Christian sect that emphasized that Jesus is two distinct persons (human and divine).
} 
accommodated almost organically, without the use of force which anyhow was not available to the Nestorian missionaries" 32 .

Perhaps the historical precedent of the successful Nestorian linguistic accommodations could be used as a model for contemporary rule-of-law work, since writing the UN principles in the language of a domestic legal system is the core objective of the UN's "good faith" technical assistance programmes.

\section{THE LAWS OF FORMAL AND UN LOGIC}

The 19th century British language philosopher Archibald Sayce observed that "had Aristotle been a Mexican, his system of logic would have assumed a wholly different form"33. But Aristotle would not have needed to travel that far from his Hellenic culture to realize that his formal logic is differently interpreted in the present EU because it is conditioned by natural language and national legal systems. In European community law, "the syllogistic model becomes clearly inadequate, because the indeterminate nature of the prescribed norms (...) is compounded by a plural structure that belongs to several non-hierarchically related and simultaneously applicable systems (national and European laws)"34.

EU legal outcomes may consequently suffer from "eccentricity"35, showing that in international law the response to the cross-national shortcomings of syllogistic reasoning has resulted in being balanced out by inductive reasoning entailing ambiguity ${ }^{36}$.

\footnotetext{
32 L. Gumiłow, Sladami cywilizacji Wielkiego Stepu [In the Footsteps of the Great Steppe Civilization], Warszawa: Państwowy Instytut Wydawniczy 2004, p. 91 (trans. by S. Michalski from Russian, Poiski wymyszlennogo carstva (Legienda o Gosudartvie Preswitiera Jaonna)).

33 A. H. Sayce, Introduction to the Science of Language, London: Kegan Paul, Trench \& Trübner 1900, vol. 2, p. 329.

34 M. Delmas-Marty, Towards a Truly Common Law. Europe as a Laboratory for Legal Pluralism, transl. by N. Norberg, Cambridge: Cambridge University Press 2002, p. 100.

35 Ibidem, p. 99.

36 G. Schwarzenberger, The Inductive Approach to International Law, London: Stevens and Sons; Dobs Ferry, New York: Oceana Publications, Inc. 1965, p. 8.
} 


\section{BIVALENT AND MULTIVALENT LOGIC}

The original syllogism, as the British philosopher Bertrand Russell said, is as sterile as the twelfth-century monks were: it denies a sensory experience ${ }^{37}$. Its crisp, compelling and linear deductive reasoning, with its discrete three-term construction, is built on the assumption that, had there not been a relation between one and the other syllogistic term, the nature of each term would not necessarily have been different ("external relation") 38 . A logical syllogism merely confirms this between one and the other term. It evidences an "objective fact".

On that relation is based the following exemplary three-term syllogism: general A. Criminals must be punished; specific B. This person is a criminal; conclusion $\mathbf{C}$. Therefore this person must be punished. This is a pertinent model in domestic Western legal systems. The reasoning in that system follows three of Aristotle's laws: non-contradiction (the true is not the false), identity (there is only one true or one false), and the excluded middle, or bivalence (all statements are true or false).

Imperfections of that national system's legal language aside, these three laws are firmly rooted in the Western intellectual tradition ${ }^{39}$. In the Chinese intellectual tradition, there is no necessary incompatibility between the belief that $\mathrm{A}$ is the case and the belief that not- $\mathrm{A}$ is the case (the law of contradiction). As in the symbol of the Tao, each side of which contains the seed of its polar opposite, A can actually imply that not-A is also the case, or at any rate soon will be the case. Events do not occur in isolation from other events. They are always embedded in a meaningful whole where the elements are constantly changing and rearranging themselves. This is a relation between two entities. Had they not been related to one another, the nature of each would necessarily have been different ("internal relation"). It only evidences a "subjective act".

An ancient Chinese folktale about a horse and a farmer shows what this open-ended relation implies. The tale starts with the farmer's horse,

\footnotetext{
37 As credited to Russell by R. Nisbett, The Geography of Thought: How Asians and Westerners Think Differently... and Why, New York: Free Press 2004, p. 203.

38 http://dictionary.reference.com/browse/internal\%20relation [last accessed: 10.12.2013].

39 Delmas-Marty, supra note 34, p. 99.
} 
which: "ran away to the nomads across the border. Everyone tried to console him, but his father said, 'What makes you so sure this isn't a blessing?' Some months later his horse returned, bringing a splendid nomad stallion. Everyone congratulated him, but his father said, 'What makes you so sure this isn't a disaster?' Their household was richer by a fine horse, which his son loved to ride. One day he fell and broke his hip. Everyone tried to console him, but his father said, 'What makes you so sure this isn't a blessing?' A year later the nomads came in force across the border, and every able-bodied man took his bow and went into battle" 40 .

The moral of the tale is that, because the son broke his hip, he could not be conscripted and thus both survived to take care of each other. The farmer refuses to be held hostage by the dilemma of "either/or" because such a choice would rule out any other outcome. His logic does not lend itself to being halted and forced to deliver a premature outcome. The story expresses a fundamental tenet of the Eastern stance toward life: it is always too early to predict outcomes in the world of constant change and contradictions represented by the symbol of the $\mathrm{TaO}^{41}$.

The farmer's thinking also opposes Aristotle's law of single identity: "[i]t will not be possible to be and not to be the same thing, except in virtue of an ambiguity"42. In his formal logic, there can be only a single identity: "'being white' and 'being a man' are different; for the former terms are much more different so that they must a fortiori mean different things" 43 . However, our Chinese farmer is open to accepting several non-identifiable future developments beyond one or the other single event. He realizes that those developments may still show another identity through adding new events that change the nature of the case in question.

The story also opposes Aristotle's law of the excluded middle: "there is no middle ground between being true and being false". It excludes the option that the answer to the "good" /"bad" question of the Chinese

\footnotetext{
40 Quoted after E.J. Langer, The Power of Mindful Learning, Reading: Addison-Wesley 1977, pp. 99-100.

41 Nisbett, supra note 37, p. 13.

42 Metaphysics, Part IV, Book 4, available online: http://classics.mit.edu/Aristotle /metaphysics.4.iv.html [last accessed: 10.12.2013].

43 Ibidem.
} 
farmer is held by developments unknown to him; he realizes that they, and not he, hold the answer. The formal logic's law of excluded middle merely states that either a proposition is true, or its negation is true: tertium non datur. But otherwise than for a European farmer, who would have decided there and then what was good or bad for him, for a Chinese farmer there is "a middle ground" (tertium datur) because he keeps an open mind about future developments that may or not add a new value. In sum, instead of a logical disjunction (a bivalent logic), a Chinese farmer has a nuanced three- or more value (multivalent) logic that allows for the incalculable. This explanation is not intended to mean that there is a Chinese counter-logic ${ }^{44}$, nor that "Eastern wisdom" speaks "the truth" 45 , but rather that there are alternative ways of thinking46.

Aware of Sayce's epigram that culturally broadened the sense of bivalent logic, Charles S. Peirce (1839-1914) ${ }^{47}$, William James (1842-1910)48, George E. Moore (1873-1958) ${ }^{49}$ and Bertrand Russell50 - albeit provoking controversy in doing so - opened the Western door to multivalent logic. Initially disregarded and pejoratively termed "fuzzy" (vague), then termed "popular philosophy" but nevertheless barred from entry to the hallowed halls of scientific logic, multivalent logic

\footnotetext{
44 "For three thousand years, there was no real jurisprudence in China. A science of logic and of rhetoric, the methods that the people could, under favourable circumstances, have used to defend themselves against injustices committed by authorities, did not develop beyond rudimentary stages" ( $\mathrm{H}$. von Senger, Chinese Culture and Human Rights, [in:] W. Schmale (ed.), Human Rights and Cultural Diversity - Europe, Arabic-Islamic World, Africa and China, Goldbach, London: Keip Publishing 1993, p. 303). Likewise in Japanese jurisprudence emphasized is the lack of logic: "[t]he reason is that the solutions provided by logic are too rigid for the varied and sophisticated problems of life: analysis distances everything from its natural state" (K. Maros, Legal Thinking in Japan, Sectio Juridica et Politica 2007, vol. XXVII, p. 89).

45 According to Ch. Hansen, "Chinese philosophers have no concept of truth at all" (idem, Language and Logic in Ancient China, Ann Arbor: University of Michigan Press 1983, p. 491).

46 "The challenge of multivalence (...) is a very large one. It asserts that all... [syllogistic terms - added] are vague and that all efforts of separation are arbitrary and artificial" (H.P. Glenn, Legal Traditions of the World, Oxford: Oxford University Press 2010, p. 369).

47 Ch. Hartshorne (ed.), Papers of Charles Sanders Peirce, Principles of Philosophy and Elements of Logic, Cambridge: Harvard University Press 1932, vol. II, p. 37.

48 W. James, The Will to Believe: And Other Essays in Popular Philosophy, Auckland: The Floating Press 2010, p. 25 and 39.

49 G.E. Moore, External and Internal Relations, [in:] G.E. Moore, Philosophical Studies, London: Routledge \& Kegan Paul 1922, pp. 276-309.

50 B. Russell, Our Knowledge of the External World, London: Allen and Unwin 1926, p. 19.
} 
does not exclude the incalculable, something that is inherent to the subject and may be in a mixed state, or may even be transcendental, but not necessarily "true" 51 . That logic permits to factor into the reasoning what is not immediately apparent, but which may eventually lead to a more holistic understanding of the internal nature of relations among things.

However, none of the five philosophers ever researched the validation process of that internal relation. Reportedly, this was first achieved by the Russian philosopher Zoya Morokhova (1994) ${ }^{52}$. In her anthropological research of the personal identities of Siberian tribes, she discovered that the outcome of tribal reasoning is the result of a round of internal exchanges amongst community-related actors. While, in principle, the three-term $\mathrm{ABC}$ syllogism exemplified earlier holds as a basic premise, conclusion $\mathrm{C}$ is not solely influenced by $\mathrm{B}$ (and B solely by $\mathrm{A}$ ), but also by $\mathrm{A}$. This $\mathrm{ABC} / \mathrm{CBA}$ syllogism reads like (mind the interpunctuation): "[a]lthough criminals must be punished (A), and this person is a criminal (B), but $\mathrm{h} /$ she may/not be punished $(\mathbf{C})^{\prime \prime}$. Still in other words, unlike in Western formal logic, in Eastern thinking A and B have more than one identity (identities do not contradict one another) due to $\mathrm{C}$ which because of some higher reason guides the choice. The outcome offers a middle ground that may be an "Eastern wisdom". The validation process may show that the outcome differs from the "truth" an Occidentalist would think of in universalistic terms.

This is what makes Eastern thinking a circular process, different from the Western linear process (Figure 1).

\footnotetext{
51 "Truth" is a narrower concept than "knowledge" (we know more about the universe, but may not know what is true about it), so a rigid deduction can only show which of the two terms (A or B) is "valid" or not ("false") but does not tell whether they are true. "Wisdom'" is the applied knowledge - ability to make correct judgments and decisions. "Folk wisdom" is a traditional knowledge.

52 Z. Morokhova, Litschnost' $v$ kulturach Vostoka i Zapada [Personality in the Cultures of East and West], Novosibirsk: Nauka 1994, as synthetized and discussed by St. Zapaśnik, 'Walczacy Islam' w Azji Centralnej. Problem Społecznej Genezy Zjawiska ['The Fighting Islam' in Central Asia. The Problem of the Social Genesis of the Phenomenon], Wrocław: Fundacja na Rzecz Nauki Polskiej 2006, pp. 45-46).
} 

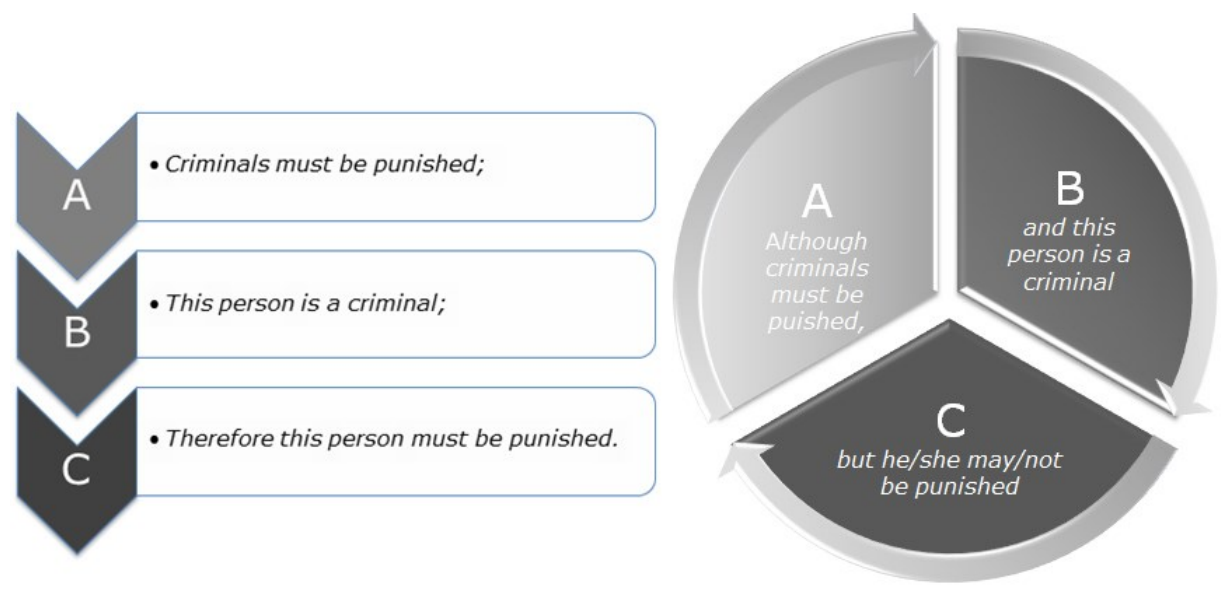

Figure 1. Formal and tribal logic

In that kind of Oriental thinking there is no "fact", "object" or "substance" (a logical or philosophical Occidental category), but an "act" or a "process".

This process is still in line with a general logical principle "whatever A and B and C may be, if all A is B, and $C$ is an $A$, then $C$ is a $B$ ". However, it does not meet the requirement of a linear formal Western logic that strictly reduces $\mathrm{C}$ to be only a consequence of what discretely and irreversibly follows from A and B. This looks, though, that there is a common ground between internal and external relation whereby "moral judgements are made in relation to an agreement" 53 - one of the fixed inter-language normative logic categories.

Above the above common principle, Occidental and Oriental ways of thinking are based on different precepts, whereby an agreement in the latter case may only cover certain moral judgments, but not all. Tribal logic is guided by personal experience and common wisdom, not by knowledge and evidence.

53 G. Harman, Moral Relativism Defended, The Philosophical Review 1975, vol. 84, no. 1, p. 4. 
The tribal example from Siberia points to the existence in Eastern moral judgements of kinship as a strong, associative regulative and integrating factor. For moral judgements in Western thinking there is, at least on paper, no regulatory role of kinship, but only reasoning based on strict formal logic that strongly took hold in the Western world in the $20^{\text {th }}$-century period of modernization.

In conclusion, Occidental and Oriental ways of thinking are different. However, "Occident" and/or "Orient" are mental concepts rather than existing objective facts. If that "(f)act" really comes into the picture, then perhaps only in its one least divisive but clearest feature, namely that of a (non)Orientally thinking person pursuing a (non)Aristotelian logic to define a particular situation. Consequently, one and the same person may be "Occidentally" or/and "Orientally" minded. Anything else is a literary myth ${ }^{54}$, a licentia poetica, but it does not mean that different ways of thinking are a scientific fiction.

\section{UNITED NATIONS LOGIC AND THE RULE OF LAW}

UN logic is, perhaps, the most extreme, baffling and complex example of multivalent logic in terms of its dimensions and the outcomes it yields. From the many dimensions, three will be noted here.

First, the lexical dimension: UN logic is a good example of fuzziness. This style of international English communication - known as "UNese" - emphasizes consensus, compromise, and accommodation and consequently lacks clarity, structure, and vigour ${ }^{55}$. Overlong sentences, overuse of nominalisations (choosing nouns over verbs) ${ }^{56}$ and the underuse

\footnotetext{
54 E. Kuźma, Mit orientu i kultury Zachodu w literaturze XIX $i$ XX wieku [The Myth of Orient and Culture of the West in the Literature of the XIX th and XX ${ }^{\text {th }}$ Century], Wyższa Szkola Pedagogiczna w Szczecinie, Rozprawy i Studia 1980, vol. XLI, pp. 119-120. In Western humanities it was French poet and parliamentarian Paul Valéry (1871-1945) who first said that Occidental "man had never been in that undefined land which he denotes" (idem, Oeuvres, vol. 2, Paris: Bibliothéque de la Pléiade 1960, p. 1041).

55 Linguistic analysis by C. Edwards in her master thesis, Challenges Facing Writers of English in International Organisations, Donau Universität, Krems 2014.The author is grateful for her opinions on the present article, but the responsibility for those expressed in it rests with him alone.

56 Verbs are more frequently used in Chinese than English (Nisbett, supra note 37, pp. 149-150).
} 
of advance organizers are common features. Ambiguous or fuzzy, it purposely leaves many international concepts indeterminate or incomplete (e.g. the intellectual shortcut "eradication of poverty").

A case in point may be the $2012 \mathrm{UN}$ resolution on the rule of law, some 2750 words long, from which only indirectly may be inferred the 2004 UN organic nature of the rule of law ${ }^{57}$. But "UNese" aside, this Declaration and other UN rule-of-law instruments reflect not only the pluralism of legal thought, but can and often do blend with non-legal provisions, e.g. on social justice or cultural specificity. The more such legal instruments are blended with concepts and terms from various fields, the less logically rigid they are. This is due to the incongruences of international legal reasoning, resulting from various national legal reasonings, sometimes fundamentally incompatible with one another.

No wonder, then, that because of that fuzziness a UN "resolution" (a play of heteronymous words) is humorously ranked lowest in clarity compared with a "resolution" of American or British origin (Figure 2).

Second, the normative dimension: UN logic, although ponderous, is appropriate for achieving a universalistic good moral end. It is a part of the UN's "moral language", behind which line up several fathers of public international law, starting from Grotius. This multivalent logic is driven by the UN rhetoric in which "in the long term all things are possible" 58 . This expert quote surprisingly comes from The UN Conference on the Application of Science and Technology for the Benefit of the Less Developed Areas.

\footnotetext{
57 Highlighted, however, in a non-binding way in the Report of the Secretary General preceding that resolution: "[a]t the national level, the rule of law is at the heart of the social contract between the State and individuals..." (UN doc. A/66/749, Delivering Justice: Programme of Action to Strengthen the Rule of Law at the National and International Levels, Report of the Secretary-General, 16.03.2012, § 4). The phrase "at the heart of social contract" prompts various conceptual issues - too many to iron them out in a global declaration on the rule of law.

58 V. Argyrou, The Logic of Environmentalism, Anthropology, Ecology and Postcoloniality, New York-Oxford: Berghan Books 2005, p. 28.
} 


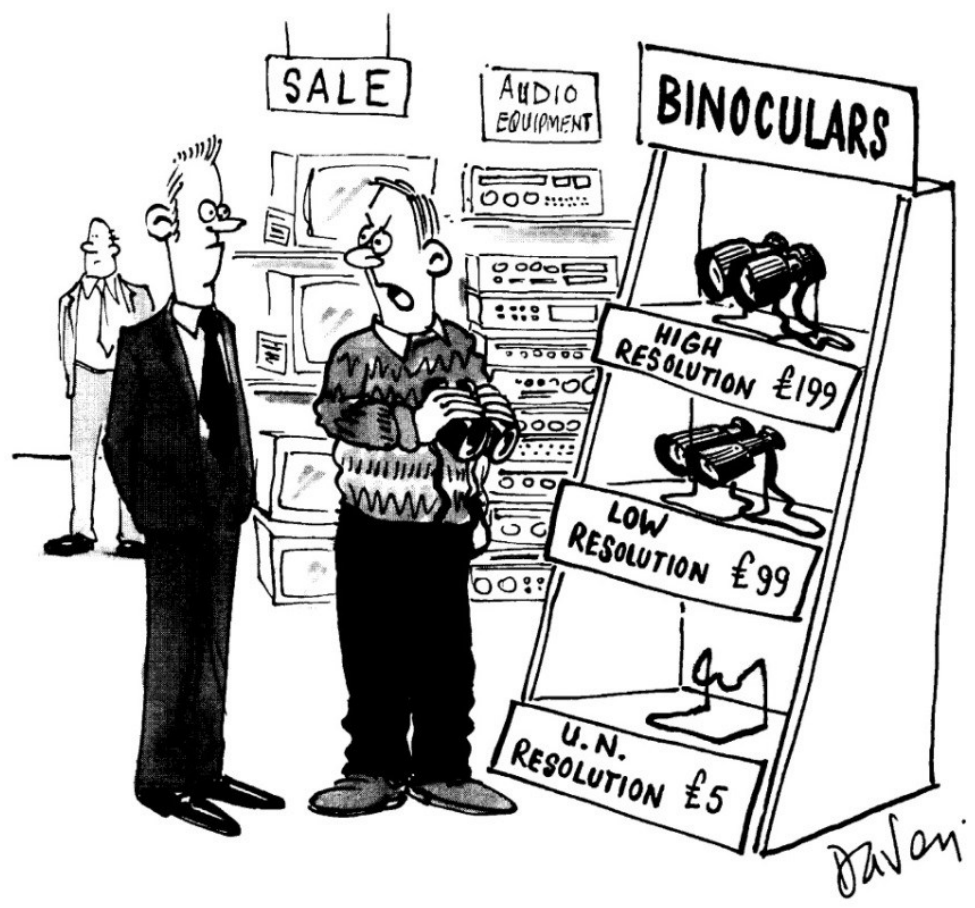

\section{"Everything looks fuzzy through these"}

Figure 2; source: CartoonStock.com. Reprinted with the permission of the copyright owner.

Science and Technology are the two disciplines at the core of which is mathematical logic ${ }^{59}$, the base of formal logic. The quotation above documents the indeterminate/open-ended outcome characteristic of multivalent logic. In UN terms, it implies evidence- and knowledgebased, as well as developmental, humanitarian and rights-based approaches. This is the mixture, not without contradictions, which drives

59 However, as Glenn points out (idem, supra note 46, pp. 369-370), in physics the sharp mathematical boundaries are now dissolving because of quantum mechanics (A. Granik, H.J. Caulfield, Fuzziness in Quantum Mechanics, Physics Essays 1966, vol. 9, no. 3, pp. 496-505). A household instance of mechanical application of fuzzy logic is a rheostat - a device that can adjust vacuum cleaner's dust sucking power; the volume of a radio or light, etc. 
multivalent logic in the UN. This logic "reconciles its own normativity with its own tolerance of other traditions" 60 .

And, indeed, if one now looks over past seven decades at the UN, thanks to the tolerance of multivalent logic, there is remarkable evidence of a normative progress in the maintenance of peace and security between 1945 and now (Figures 3 \& 4).

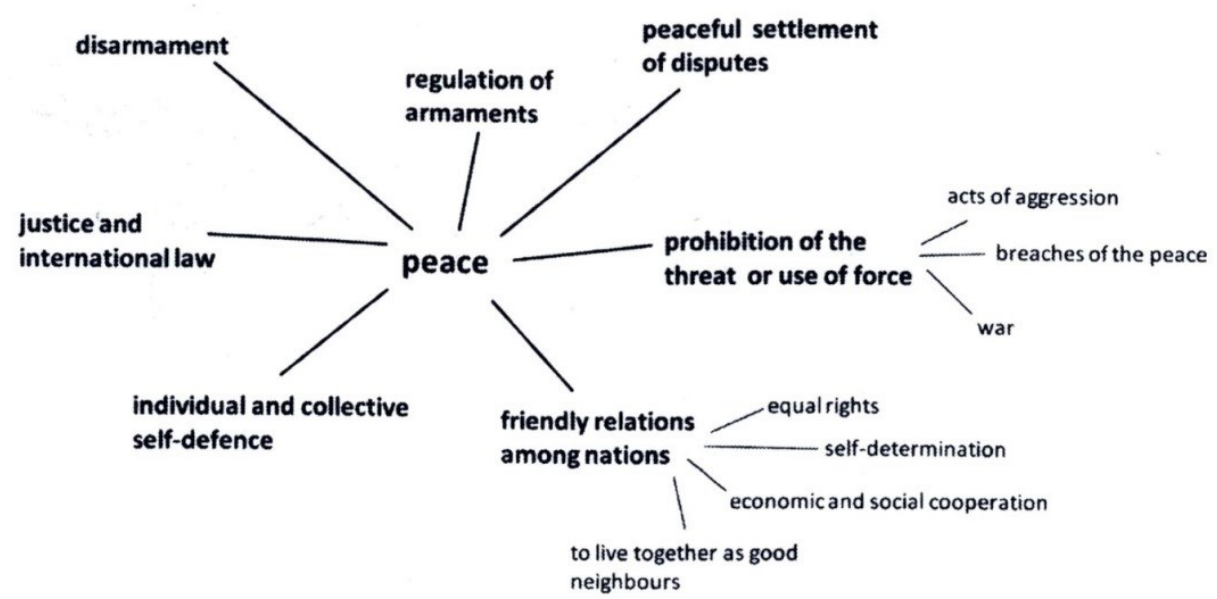

Figure 3. The normative dimension of the UN Peace concept as of 1945 Source: Harfensteller, supra note 4, p. 303.

Both figures have descripted lines. These are lexical markers ${ }^{61}$. They represent semantic relations to the word "peace" in 1945 and now. Figure 3 shows that in 1945 there was virtually nothing to support "peace", neither by the "rule of law" nor, let alone, "justice". Currently "justice", "rule of law", "human rights", "humanitarian law", "peaceful settlement",

60 Glenn, supra note 46, p. 365.

61 The lexical markers depict some of the principles, values, and objectives that are deemed indispensable for the achievement of peace world-wide and at a country-level (Harfensteller, supra note 4, p. 303). These markers are English nouns, verbs, adjectives and adverbs encoded through computational linguistics and natural language processing and linked via an algorithm for semantic/conceptual relations that determine word definitions (G. A. Miller, 'WordNet': A Lexical Database for English, Communications of the ACM 1995, vol. 38, no. 11, pp. 35-41). 
"democracy", "good governance", and "sustainable development" (several of them sub-branched) form almost a full panorama of markers supporting "peace" (Figure 4).

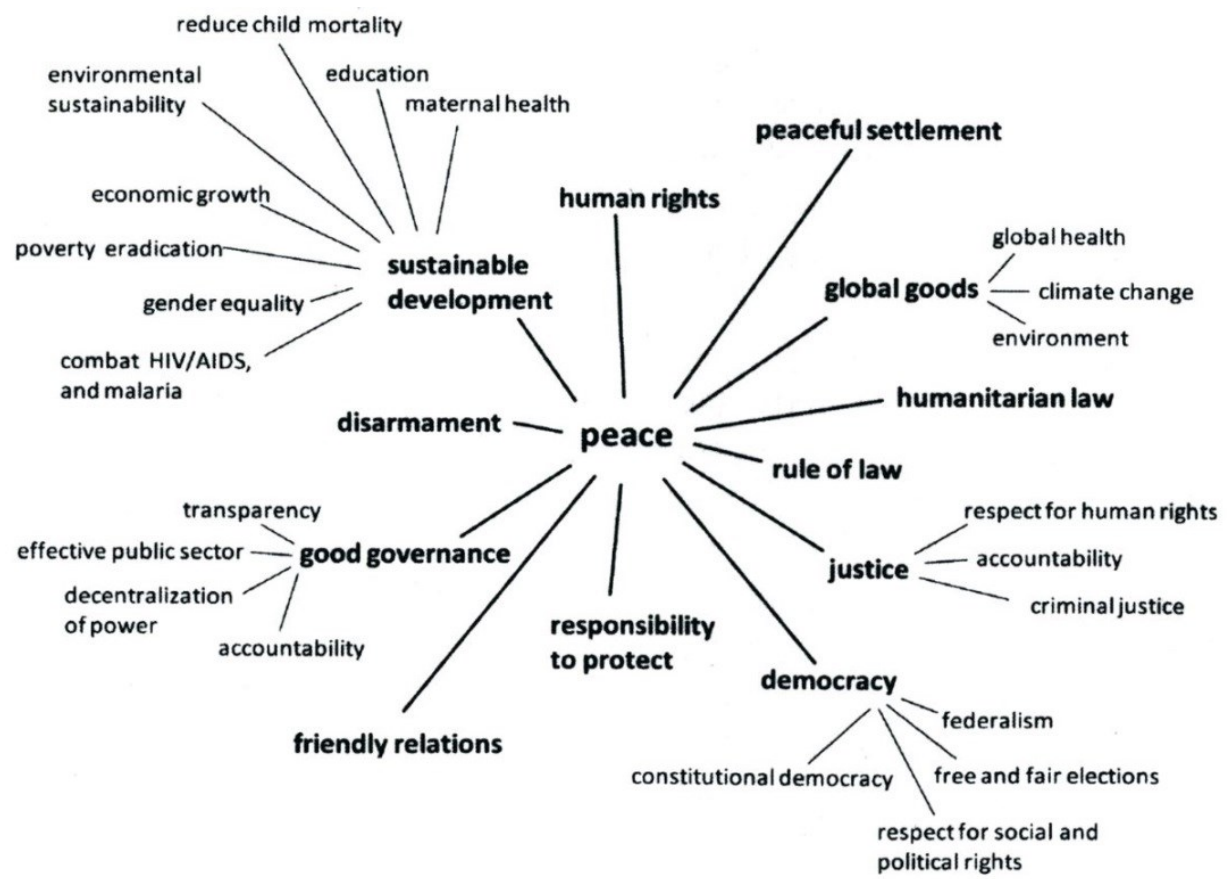

Figure 4 . The normative dimension of the contemporary UN Peace concept Source: Harfensteller, supra note 4, p. 303.

Third, the strategic dimension: driven by one basic UN goal to achieve one outcome: to save succeeding generations from the scourge of global war by maintaining peace and security in the world, the UN has so far managed this on a broad international plane.

\section{EDUCATION IN THE UNITED NATIONS RULE OF LAW}

A different case is with implementing the UN rule-of-law legal instruments in education. The UN Declaration on the Rule of Law stressed only: "the importance of international cooperation and invite donors, regional, subregional and other intergovernmental organizations, as well as relevant civil society actors, including non-governmental 
organizations, to provide, at the request of States, technical assistance and capacity-building, including education and training on rule of law-related issues, as well as to share practices and lessons learned on the rule of law at the international and national levels" 62 .

Several technical assistance UN rule-of-law projects involve training, but not education.

The Organization voices its educational calls through initiative like "Education for All" or by the United Nations Academic Impact Initiative. But these initiatives are a "window dressing". They merely sensitize the international audience to certain concerns left to its own designs and devices. In this connection, Western States (the United States and the United Kingdom especially) have far more to say about rule-of-law education, and the previously cited 2013 book of the American Bar Association is a good case in point.

Beyond even the clichéd mentions of "cultural specificity" in that work, the relevance of culturally different ways of thinking and acting for the ends of the rule-of-law has scarcely been noted and discussed. Those who have done so, rightly observed that informal agreements and sanctions found effective in developing countries involve structures of power, procedure, personnel and "language of mediation" different from developed countries ${ }^{63}$. Another author concluded, after her eight-year experience of teaching criminology at the University of the West Indies in Trinidad, that Western textbooks she used in her classes were as likely to be misleading, or at best to miss the point, as to be helpful. The texts denied the possibility of difference or seek to explain it away. They neither had a concept that would bridge the gap between Occidental and Oriental ways of thinking for rule-of-law ends nor provided a clue how countering crime, i.e. violence against women and children, can be pursued in successful technical assistance terms. She concluded that to see the same mechanisms for countering crime in developed and developing countries "is romantic nonsense (let alone bad sociology)" 64 .

62 UN doc. A/RES/67/1, § 38 .

63 Ch.B. Harrington, S.E. Merry, Ideological Production: The Making of Community Mediation, Law \& Society Review 1988, vol. 22, issue 4, p. 710.

64 M. Cain, Orientalism, Occidentalism and the Sociology of Crime, British Journal of Criminology 2000, vol. 40, p. 241. 
This nonsense was first clearly evidenced by the criminological findings that the nascent Social Learning theory dealt with in the $20^{\text {th }}$ century. They were first based on the 1850s-1930s anthropological findings on behaviour of "criminal tribes" 65 of India. Those findings showed a very strong regulatory role of kin groups in arriving at what is just or not for them and others. Their researched code of conduct has had two standards: killing a member of another tribe or stealing from him was not a "crime", but doing that to own tribe members was.

On the basis of the study of their conduct norms that are intergenerationally passed to their offspring and other kins, Thorsten Sellin, an eminent Swedish/US sociologist of the $20^{\text {th }}$ century, claimed that in the above situation, it is as "natural for the Chinaman to gamble as for a baby to drink milk"66. Hence the normative "conflict of cultures" in which a group instils the double standards that its members apply.

65 So termed by the British Criminal Tribes Act (1871), see: Y.C. Simbadri, Denotified Tribes, A Sociological Analysis, New Delhi: Classical Pub., Co. 1991, p. 119 et seq. They were members of small spy rings, musclemen and private armies, known also of their virtuous internal life style. At the time of the Act there were some 45 million members of "criminal tribes". After the invasion in the $16^{\text {th }}$ century of the Sultanate of India by Central Asian nomadic tribes (which established themselves there as Moghuls (ex-Mongols)), these groups were fought and dismantled. However they resurfaced under the Moghul rule and had become a public menace as kin-based robbers and other thugs specializing in various forms of crimes, either by violence or deceit. The Moghul tribal conduct had likewise double standards (see further: S. Redo, Organized Crime and Its Control in Central Asia, Huntsville: Office of International Criminal Justice 2004, ch. 4). Both "criminal tribes" were the generic predecessors of today's professional thieves and other criminals, first studied in the sociology of deviance in the 1940s and 50s. In that sociology their conduct blended into the concept of "criminal traditions". It informs about the historical background of transmission of values and the antecedents of Social Learning theory. Since 1952 by the Habitual Offenders Act the "criminal tribes" of India have been officially termed as "denotified". They now amount to some 60 million. In 2007, the UN Committee on the Elimination of Racial Discrimination in its concluding observations expressed the concern on "the so-called denotified and nomadic tribes which are listed for their alleged 'criminal tendencies' under the former Criminal Tribes Act (1871) continue to be stigmatized under the Habitual Offenders Act (art. 2 (1) (c)", UN. doc. CERD/C/IND/CO/19, Concluding Observations of the Committee on the Elimination of Racial Discrimination, $\S 11,5.05 .2007$. This concern draws the attention of international social justice reformers, social learning theorists and educators to the need to revisit this type of intergenerational maladaptation problem that in sociology had initially been addressed without considering the economic and biosocial aspects of it. Both aspects may challenge the original theoretical assumption of a social basis of learning behaviour.

66 T. Sellin, Culture Conflict and Crime, New York, Social Science Research Council Bulletin 1938, vol. 41, p. 86. 
This historical normative conflict between tribal and state law clearly persists in India until now ${ }^{67}$.

Against this fact, one road for showing the uneasy relation between tribalism and statehood is the first motto of this article. Another one would be the second motto. It suggests that educating in the UN rule-of-law should relationally be very nuanced.

The following World Bank sociological education study ${ }^{68}$ findings are first in this order.

In an econometric experiment primary school (sixth and seventh grade) Indian low-caste and highest-casts boys (642 altogether, respectively divided in two halves), were asked to play a monetary incentive game by solving as many mazes as they could out of a given packet. When first caste was not publicly announced, there were no caste differences in performance. However, when the caste was publicly announced, the number of mazes solved by low caste boys dropped by a dramatic $25 \%$. When caste was announced, but a random draw of a name determined who in a session of 6 would be paid for the mazes he solved, the caste gap in performance disappeared. According to the authors, the findings suggest that the aggregate effect of economic deprivation (injustice) on the expectations associated with caste is clearly negative.

In the second experimental game on a smaller group of low and high-castes Indian schoolboys the authors of the same World Bank study tested those expectations separately. The authors found that indeed their pre-defined content like a self-fulfilling prophecy locks the respondents into economic disadvantage. This is not a consequence of a "culture of poverty" per se, the authors say, but its enduring legacy that facilitates the division of people into categories and shapes their beliefs and expectations.

The authors conclude that the self-perpetuation of beliefs and expectations happens in many more societies than has been broadly

\footnotetext{
67 "Though they are termed as tribes, for all practical purposes they were treated as castes in the traditional rural society" (M. Bokil, De-notified and Nomadic Tribes. A Perspective, Economic and Political Weekly, 12.01.2002, p. 148).

68 K. Hoff, P. Pandey, An Experimental Investigation of an Indian Caste, World Bank Policy Research Working Paper 06.2004, no. 3351, available online: http://elibrary.worldbank.org/doi/pdf/10.1596/1813-9450-3351 [last accessed: 10.12.2013].
} 
recognized in the economics literature. But these findings suggest also that the behavioural tribal logic may be unlocked by modern education and the "logic" of a market society, as soon as one realizes the importance of one's own progressive expectations for one's own future ${ }^{69}$.

Results of various developmental psychology experiments on children qualify culturally the above observation, as far as the controls for their logical conduct are concerned and the future they may see. In two experiments $^{70}$ on filial piety bonds, a sizeable group of pre-selected, psychologically, socially, and linguistically classified Icelandic and Chinese children was separately interviewed on two dilemmas: a moral one on friendship obligations, and another one on interpersonal responsibilities in a parent-child relationship.

In the friendship dilemma, a protagonist (successively tested at the ages of $7,9,12,15$ and 19) had to choose between keeping a promise to a best friend or accepting an interesting invitation from another child of the same gender, but new in the class ${ }^{71}$. The dilemma involved an interesting offer made by the friend or the new child (the hedonistic

69 This is what the aforementioned United Nations Conference on the Application of Science and Technology (1963) had been wanting: "[o]ne of the main objectives would he to help foster a modern, scientific attitude among the population of the developing countries generally, so as to facilitate the acceptance of useful innovations. This is a complicated and difficult matter involving an organic process about which too little is as yet known. There are risks in any attempt to transfer modern knowledge and techniques from a society in which they evolved to another society whose habits and thinking, methods of work and way of life are entirely unprepared for them. The commitment to the cause of development implies that these risks must be accepted, but clearly what must also be accepted is the responsibility, when attempting to hasten the process of transfer and human adaptation, to make sure that the most painstaking attention has been given to all that is involved" (UN doc. E/3772, § 238 at p. 79, available online: http:/ / babel.hathitrust.org/cgi/pt?q1=painstaking;id=coo.31924013846021;view=plaintext;s eq=85;start=1;size=10;page=search;num=79 [last accessed: 10.12.2013]).

70 M. Keller, W. Edelstein, T. Krettenauer, F. Fu-xi, F. Ge, Reasoning about Moral Obligations and Interpersonal Responsibilities in Different Cultural Contexts, [in:] W. Edelstein, G. Nunner-Winkler (eds), Morality in Context, Amsterdam: Elsevier 2005, pp. 317-337. The methodological description of both experiments, including the text above and in the two footnotes immediately below, comes from that publication.

71 Some aspects made the situation psychologically more complicated. For example, that the meeting with the friend is on their special day or that the old friend appears not to like the new child, and that he or she wants to talk about something that is important for him. 
concern), the moral obligation to keep the promise or the arrangement with the friend, interpersonal responsibilities of care (the long-term friendship and the needs and feelings of the close friend) and finally, the responsibilities towards the third child who is alone.

The authors reported that as regards cultural differences in orientation to the principles of justice and care (reasoning about the option who is a "friend"), Icelandic participants were more frequently oriented towards the contractual aspect of the promise. However, the Chinese, apparently prompted by altruism, were more concerned with interpersonal responsibilities towards the friend.

In the parent-child dilemma, a mother has promised her daughter that she can spend the money she has earned herself, or received as a present, on a movie or a concert. At the last minute the mother claims the money from the daughter because it is needed to buy things for school. The daughter lies about the amount of money and goes to the movie or concert - with the knowledge of her sister. The dilemma focuses on the sister (first tested at the age of 12, then at the age of 15) who has to decide whether she should tell her mother the truth or be silent about it when the mother asks her about the sister's whereabouts ${ }^{72}$. The interview strategy concentrated exclusively on the moral judgment and the reasons supporting it. In addition, however, respondents were asked for justifications that might support an alternative moral judgment of a fictitious third person.

The authors further report that in evaluating the results of that dilemma, it turned out the contractual aspect the mother had given to her daughter had for 15-year-olds a somewhat greater significance for them than for the corresponding Chinese group. But a closer look at the arguments in both groups more importantly suggested a bigger significance of fairness over sibling loyalty in the Icelandic parent-child relationship. For the Chinese children it was their preference of parental authority (not fairness, but submissive filial piety)

\footnotetext{
72 Again, the conflict contains different concerns. Beyond the issues of parental authority and the contractual norm of promise keeping the moral norm of truthfulness - not to lie to the mother, and interpersonal responsibilities such as care or loyalty to the sister are important concerns in the situation (see further, M. Keller et al., supra note 70).
} 
over sibling loyalty - penultimate on the list of the 5 Confucian bonds ${ }^{73}$. On the contrary, for the Icelandic group's conduct it appears that fairness was a part of an emerging moral egalitarian contract between a parent and a child.

The above suggests that the regulatory force of the kin instinct differed in both groups, and that different bonds were at work that influence contractual rules. However, limited space allows neither a review of the voluminous rule-of-law, let alone criminologicaly, nor relevant aspects of kinship, nor yet the regulatory role of urbanization and college education in fairness, locally and interculturally ${ }^{74}$.

Further, space limits allow us only to note that in the early beginnings of the UN, at its invitation, the World Health Organization published ${ }^{75}$ a psychological study comparing affective bonding of an opportunity sample and control group of juvenile delinquents. The study revealed that early (first 24 months after birth) maternal deprivation of their caretaking as toddlers had been found significantly related to their later conflict with the law. Ever since that publication, many other studies have covered various culturally diversified (non)delinquent groups, and have likewise corroborated that affective bonding between parents and children prevents delinquent behaviour.

Finally, the United Nations Children's Fund ${ }^{76}$ reported on scientific studies indicating the neurological pathway of mother-child affective bonding through hormonal connection between one another. Coincidentally, this corroborates Sellin's claim. After all, this claim may be not so metaphorical as was in 1938. But now the thesis on affective bonding by hormones requires a closer analysis of their interplay with social factors, e.g. learning how both determine moral choices (fairness $v$. filial piety/sibling loyalty), or emotional/intuitive and intellectual choices that both may allow less or more fairness ${ }^{77}$.

\footnotetext{
73 See supra note 27.

74 See further S. Redo, M. Platzer, supra note 20.

75 J. Bowlby, Maternal Care and Mental Health: A Report Prepared on behalf of the World Health Organization as a Contribution to the United Nations Programme for the Welfare of Homeless Children, Geneva: World Health Organization, Department for Children and Parents 1951.

76 UNICEF, Early Child Development. The Key to a Full and Productive Life, New York (no date).

77 In line with the intuitional approach, moral judgment is not so much grounded in a universalistic language pattern (see supra note 10) as in automatic emotional responses
} 
Two general observations follow from the above review of various educational and developmental studies on fairness. The first regarding kinship, other bonding and fairness, is encapsulated by the reminder of the second motto. Cicero continues: "[b]ut a still closer social union exists between kindred. Starting with that infinite bond of union of the human race in general, the conception is now confined to a small and narrow circle. For since the reproductive instinct is by Nature's gift the common possession of all living creatures, the first bond of union is that between husband and wife; the next, that between parents and children; then we find one home, with everything in common. And this is the foundation of civil government, the nursery, as it were, of the state. Then follow the bonds between brothers and sisters, and next those of first and then of second cousins; and when they can no longer be sheltered under one roof, they go out into other homes as into colonies"78.

Against this motto, the psychological experiment on filial piety shows that a parent-children relationship in Western thinking is theoretically similar to Confucius', but in practice a child is less submissive to a parent and more independent.

Second, regardless of the provenience of those studies, they, and the other evidence and arguments earlier presented, confirm that:

- justice starts at home and may progress with the education as it continues through the adulthood,

- education and equality in justice ${ }^{79}$ matter as controlling factors for the direction of moral judgements and choices, culturally and generally.

If the moral judgements and choices are directed, how this can be helpful for the intercultural rule of law education in the UN?

and complex computations tracking the intentional structure of social interactions (E. Dupoux, P. Jacob, Universal Moral Grammar: a Critical Appraisal, Trends in Cognitive Sciences 2007, vol. 11, no. 9, pp. 373-378). This reminds of the interpretation that morality is biologically inherent, originally discussed by Hobbes, Grotius and Pufendorf (supra note 14). See further: P.S. Churchland, Braintrust. What Neuroscience Tells Us about Morality, Princeton: Princeton University Press 2011.

78 Miller, supra note 61, pp. 57-58.

79 See supra note 18. 
Based on the findings from the international management theory on a cultural interaction with a local workplace, Figure 5 shows how one may glocally reconcile cultural relativism in applying the UN rule of law for education and other local reforms ${ }^{80}$.

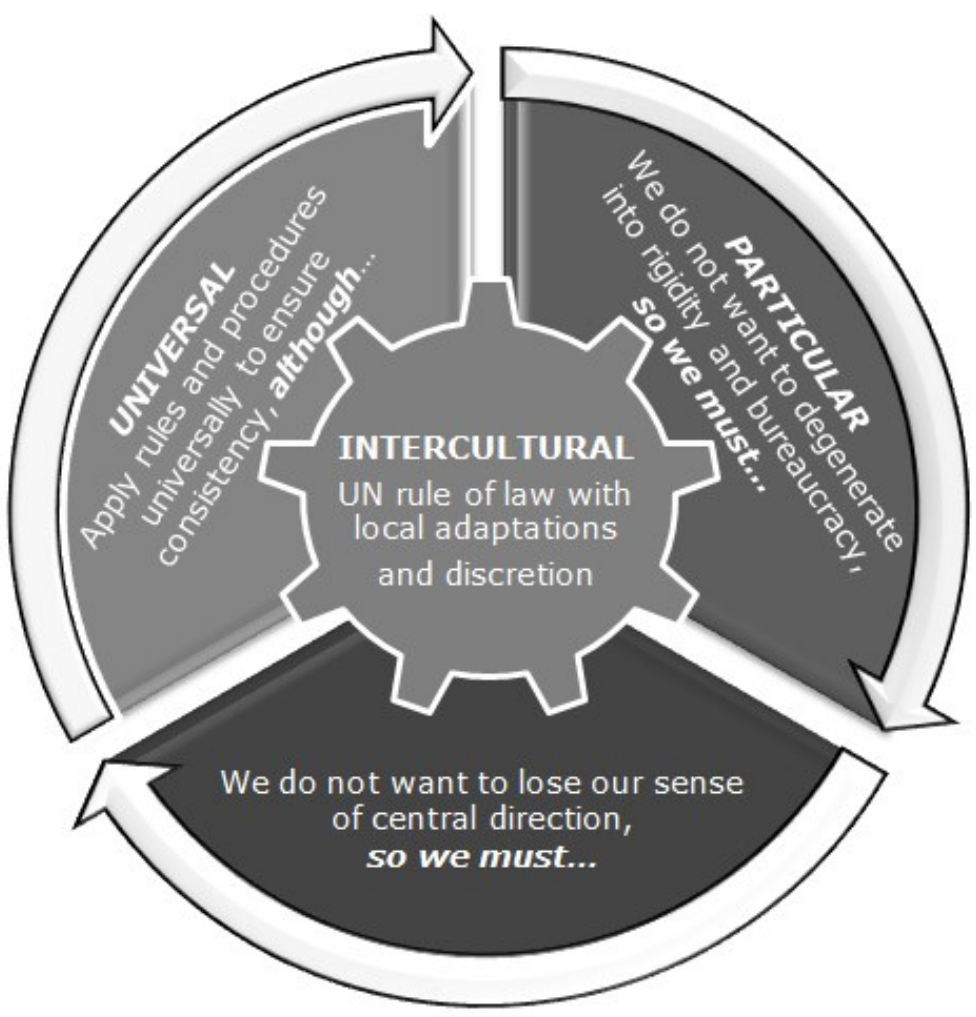

Figure 5. Globalizing United Nations rule of law through local learning Adapted from: Trompenaars, supra note 80, p. 32.

80 F. Trompenaars, Law Across Cultures: An Overview, [in:] R. Blanpain (ed.), Law in Motion. International Encyclopaedia of Laws. Recent Developments in Civil Procedure, Constitutional, Contract, Criminal, Environmental, Family \& Succession, Intellectual Property, Labour, Medical, Social Security, Transport Law, World Law Conference (Brussels, 9-12 September 1996), Dordrecht: Kluwer Law International 1997, pp. 27-46, adapted with his explanation, separately contextualized. 
Research has shown that human organizations with the most effective change programmes have developed a culture of dialectics ${ }^{81}$. Figure 5 shows that when dealing with domestic rule-of-law reform, one may be caught in the dilemma of applying a universal rule to a local circumstance. A good practitioner reconciles this by acknowledging that the local instances need universal rules in order not to slip into an unwarranted local specificity. Strategic rule-of-law reform is not about replacing one orientation by another. It puts one orientation in the context of the other, rather than opposing values.

As noted in the previously cited publication, the elegance of this approach is that the existing culture is not threatened, but enriched. Being universal means to be enriched by the other particular human values and letting them flourish for a common good. And just as English has become a global language, no part of the developed and developing world can remain unaffected by the global standards and norms, including the UN law. This broadens a pattern of normative understanding ("common language of justice") of problems and contributes to the UN Charter's cooperative vision of international life.

\section{ENDNOTES}

The above mechanism of reform for the UN rule of law applies to pursuing both individual and structural changes. It applies to teaching students the UN Rule of Law, but also "writing it into" domestic law and "talking into it" others and learning from them.

In fact, this is:

- how the text of the UN General Assembly Declaration on the Rule of Law emerged (adopted unanimously, i.e. by negotiating and arriving at a global consensus through compromising on the national specifics) - a landmark achievement and proof of "globalization through local learning"; and,

81 K. Peng, R.E. Nisbett, Culture, Dialectics and Reasoning about Contradiction, American Psychologist 1999, vol. 54, pp. 741-754; M.P. Lopes, A Dialectical Approach to Positive Organizational Studies, American Journal of Industrial and Business Management 2013, no. 3, pp. 185-195. 
- also the way in which the conclusion should be read of the World Bank study on unlocking the cycle of self-sustained poverty by changing people's expectations, not only by analysing the mechanisms which may or not be conducive to modifying their expectations, but also by providing avenues and educational content that enable advancing access to "justice" - an international developmental public good that depends on learning the lessons from the domestic field.

Until now, the UN's counteraction to various rule-of-law challenges has been driven by the Powers of the developed world. At around the date of the Fourteenth UN Congress on Crime Prevention and Criminal Justice (2020) the overall balance of economic power in the world will be tipped by in favour of developing countries (China and India among them). Emerging economies will rise in importance and China will have surpassed the USA on the list of world's ten largest economies in GDP terms ${ }^{82}$. By $202552 \%$ of the global output may be delivered by emerging and developing economies, and $48 \%$ by advanced economies ${ }^{83}$.

As the Secretary-General of the Organization for Economic Cooperation and Development concluded: "[t]he world our children and grandchildren inherit may be starkly different from ours" 84 . A new "hegemonial logic" 85 will start taking hold of the minds of peoples. What will be the orientation of the UN Rule of Law and the UN's capacities in normative language, logic and judgement? The 2011 World Bank Report estimated that the average time taken by the 20 fastest-growing developing countries to reach threshold levels on the rule of law based on World

82 www.therichest.org/world/worlds-largest-economies/ [last accessed: 10.12.2013].

83 Altogether 55 countries (see further: Global Economic Outlook 2014, available online: http://www.conference-board.org/data/globaloutlook.cfm [last accessed: 10.12.2013]). "Output" means here capital plus labour inputs plus a residual (salvage) value composed of a value of technological progress plus production efficiency remaining as an asset after it has been fully depreciated.

84 A. Curia, quoted in: Balance of Economic Power Will Shift Dramatically Over the Next 50 Years, Says OECD, available online: http://www.oecd.org/newsroom/balanceofeconomic powerwillshiftdramaticallyoverthenext50yearssaysoecd.htm [last accessed: 10.12.2013].

85 R.A. Falk, Theoretical Foundations of Human Rights, [in:] R.P. Claude (ed.), Human Rights in the World Community: Issues and Action, Philadelphia: University of Pennsylvania Press 1992, p. 34. 
Bank governance indicators is 42 years $^{86}$. The question is: What sort of governance indicators will there be in 40 years from now? Will there be less or more checks and balances?

Contrary to a view that a new "hegemonial logic" may weaken the UN Rule of Law, there have been very successful instances of the embracing by the UN (originally flawed in terms of checks and balances) of legal institutions that create a new vision of life and extend the limits of our world. The example involves the introduction in 2002 of the UN principles on restorative justice. This form of alternative justice, earlier dismissed in Western academia as, reportedly ${ }^{87}$, orientalised, romanticised; "mythical", "impossible" 88 and, eventually, warned against 89 , has been approved by the Organization. The UN did so on the premise that in Member States "fundamental procedural safeguards guaranteeing fairness to the offender and the victim should be applied to restorative justice programmes and in particular to restorative processes" (the right to consult with legal counsel, the right of minors to the assistance of a parent or guardian, the right to be fully informed, the right not to participate) ${ }^{90}$.

This example indicates also that within the framework of the United Nations Studies the door is wide open for interdisciplinary exchanges and results fostering the progressive development of international law as stipulated by the UN Charter. But the progress in it cannot be solely measured by the adoption of new legal instruments or, let alone, say, by a translation of the 2012 UN Rule of Law Declaration from the 6 official UN languages into the world's 6-8000 other natural languages.

Recalling the rule-of-souls Nestorian missionaries' example, the UN rule-of-law implementation is about the rule of peoples' hearts

\footnotetext{
86 World Bank Development Report 2011, Washington, D.C.: World Bank 2011, p. 11.

87 Cain, supra note 64, pp. 244, 258.

88 P. Fitzpatrick, The Impossibility of Popular Justice, Social \& Legal Studies 1992, pp. 199-215.

89 "In the host communities to which the models have been imported those who already have rather few enforceable rights may find themselves with even fewer" (Cain, supra note 64, p. 242).

90 UN doc. ECOSOC resolution 2002/12, Basic Principles on the Use of Restorative Justice Programmes in Criminal Matters, 24.07.2002. As a UN staff member the author was present at the time of adopting these principles by the United Nations Commission on Crime Prevention and Criminal Justice. Hardly any observer believed that this could happen.
} 
and minds to deliver in practice the human rights ideas for justice to a single nation and person.

Charles de Montesquieu (1689-1755) in The Spirit of the Laws was negative about whether delivering such ideas is at all possible in some places, and gave the example of Asia ${ }^{91}$. Intercultural management theorists have a less pessimistic and more hands-on approach to dealing with "particular $v$. universal". In their view (as earlier noted), one may overcome built-in cultural resistance to external change by adjusting it to local conditions and globalizing local learning.

First, in this way, they recast his Spirit: "Montesquieu argued that there is such a thing as 'the general spirit of a nation' (what we now would call its culture) and that ' $[\mathrm{t}]$ he legislator should follow the spirit of the nation (...) for nothing better than what we do freely and by following our natural genius' ${ }^{92}$. Thus institutions follow mental programs, and in the way they function they adapt to local culture. Similar laws work out differently in different countries, as the European Union has experienced on many occasions (...). An important consequence of this is that we cannot change how people in a country think, feel and act simply by importing foreign institutions (...). Each country has to struggle through its own type of reforms, adapted to the software of the minds of its people" 93 .

Second, they also noted that in comparison with non-governmental organizations, like Amnesty International or the International Committee of the Red Cross, the UN's "missionary" zeal is very superficial.

Finally, the authors submit that the United Nations because of its diplomatic culture is less for shared values, but more for superficial levels of practices, common symbols, and rituals ${ }^{94}$.

\footnotetext{
91 " $[\mathrm{T}]$ here reigns in Asia a servile spirit, which they have never been able to shake off, and it is impossible to find in all the histories of that country a single passage which discovers a freedom of spirit; we shall never see anything there but the excess of slavery" (Ch. Baron de Montesquieu, The Spirit of Laws, transl. by T. Nugent, New York: Cosimo 2011, p. 269).

92 Ibidem, p. 294.

93 G. Hofstede, G.J. Hofstede, Cultures and Organizations. Software of the Mind, New York: McGraw-Hill 2005, pp. 19-20.

94 Ibidem, p. 340.
} 
These three arguments combined imply that neither can Asians reform themselves ${ }^{95}$ nor can the UN do this across the world. The Asian democracies of India, Japan and The Republic of Korea, among others, show that Montesquieu's first view was prejudicial, as certainly prejudicial is the assumption that there is only one kind of logic. Hopefully, the rest of the arguments in this article encourage the thought that the UN can successfully influence through its own logic people's hearts and minds across the world for the Rule of Law in a "common language of justice". Beyond diplomatic culture, the UN Secretary's-General involvement in the rule of law is at the very heart of the Organization's mission (sec. 1). It is not perfunctory insofar as regards the organic involvement in rule of law operations and programming of over $40 \mathrm{UN}$ entities in 110 countries $^{96}$.

\section{CONCLUSIONS}

As a contribution to the United Nations Studies this article has focussed on: the linguistic side of logic which may be (in)formal and multivalent, as it is in the UN; UN metaphorical language of "a common language of justice"; (c) the ensuing educational aspects for the UN Rule of Law.

Regarding language, one may now reread what the US linguist relativist Benjamin Lee Whorf (1897-1941) observed: "We cut nature up, organize it into concepts, and ascribe significances as we do, largely because we are parties to an agreement to organize it in this way - an agreement that holds throughout our speech community and is codified in the patterns of our language"97. That "speech community" has universals. They are, metaphorically speaking, coded into the pattern of UN common language of justice, with "justice" upfront.

\footnotetext{
95 A crown example of resistance to reform is the following quotation: "[t]he codices of the West were made for people with a rational mind. The application of modern law contradicts the mystical sentimentalism of the Japanese, who are keen on poetry rather than logic" (Maros, supra note 44, p. 92).

96 United Nations and the Rule of Law, http://www.un.org/en/ruleoflaw/ [last accessed: 10.12.2013].

97 B.L. Whorf, [in:] J.B. Caroli (ed.), Language, Twilight and Reality: Selected Writings, Cambridge: MIT Press 1976, p. vii.
} 
Metaphorically also, in a spirit of "language universals"98, one may likewise reread what other intellectuals argued about the role of language. Federico Fellini (1920-1993, Italian film maker) said: “A different language is a different vision of life" 99 . Or, as conclusively put by the Austrian philosopher Ludwig Wittgenstein (1889-1951), "[t]o imagine a language means to imagine a form of life"100, and: "the limits of our language mean the limits of our world"101.

Regarding logic, despite differences, all people may and can think in the same way, and specific ways of thinking allow anybody to use it for whatever ends.

Regarding the UN rule-of-law education, living with diversity requires getting to know each other better and pursuing in the interest of the UN Charter their own ways of thinking in a common language of justice and for justice. Wherever "a stunning corset"102 in education perpetuates clichés and injustice, it must be unlaced.

The United Nations in which "in the long term all things are possible"103, may open the door to a new post-2015 world with an agenda for education responding to a new balance of power within its Rule of Law.

98 See supra note 10.

99 B. Cardullo (ed.), Federico Fellini. Interviews, Jackson: University of Mississippi Press 2006, p. 178.

${ }^{100}$ For a discussion, see: D.K. Barry, Forms of Life and Following Rules, A Wittegensteinian Defence of Relativism, Leiden-New York-Köln: Brill 1996, ch. 4; and J.B. White, Justice as Translation: An Essay in Cultural and Legal Criticism, Chicago: University of Chicago Press 1990, p. ix.

101 Wittegestein's "my" replaced by “our" by Bernard Williams (1929-2003, the US philosopher). See: B. Williams, The Sense of the Past. Essays in the History of Philosophy, Princeton: Princeton University Press 2006, p. 374.

102 G. Allport (1897-1967, US moral psychologist, pioneer of prejudice studies) quoted in: M. Filpisan, A.E. Tomuletiu, M. Gyorgy, T. Moldovana, Practical Guide of Intercultural Education, Procedia - Social and Behavioral Science 2012, no. 46, p. 5523.

103 See supra note 58 . 
